\title{
Verplegingswetenschap en de verpleegkundige praktijk : een onderlinge relatie
}

Citation for published version (APA):

Huijer Abu-Saad, H. (1990). Verplegingswetenschap en de verpleegkundige praktijk : een onderlinge relatie. Rijksuniversiteit Limburg. https://doi.org/10.26481/spe.19901130hh

Document status and date:

Published: 30/11/1990

DOI:

10.26481/spe.19901130hh

Document Version:

Publisher's PDF, also known as Version of record

\section{Please check the document version of this publication:}

- A submitted manuscript is the version of the article upon submission and before peer-review. There can be important differences between the submitted version and the official published version of record.

People interested in the research are advised to contact the author for the final version of the publication, or visit the DOI to the publisher's website.

- The final author version and the galley proof are versions of the publication after peer review.

- The final published version features the final layout of the paper including the volume, issue and page numbers.

Link to publication

\footnotetext{
General rights rights.

- You may freely distribute the URL identifying the publication in the public portal. please follow below link for the End User Agreement:

www.umlib.nl/taverne-license

Take down policy

If you believe that this document breaches copyright please contact us at:

repository@maastrichtuniversity.nl

providing details and we will investigate your claim.
}

Copyright and moral rights for the publications made accessible in the public portal are retained by the authors and/or other copyright owners and it is a condition of accessing publications that users recognise and abide by the legal requirements associated with these

- Users may download and print one copy of any publication from the public portal for the purpose of private study or research.

- You may not further distribute the material or use it for any profit-making activity or commercial gain

If the publication is distributed under the terms of Article $25 \mathrm{fa}$ of the Dutch Copyright Act, indicated by the "Taverne" license above, 


\section{VERPLEGINGSWETENSCHAP EN DE VERPLEEGKUNDIGE PRAKTIJK.}

\section{EEN ONDERLINGE RELATIE.}

\section{REDE}

Uitgesproken bij de aanvaarding van het ambt

$$
\text { van Hoogleraar in de }
$$

Verplegingswetenschap

aan de Faculteit Gezondheidswetenschappen

van de Rijksuniversiteit Limburg te Maastricht

$$
\text { op } 30 \text { november } 1990
$$

door

Dr. H. Huijer Abu-Saad 
2 


\section{VERPLEGINGSWETENSCHAP EN DE VERPLEEGKUNDIGE PRAKTIJK EEN ONDERLINGE RELATIE.}

Mijnheer de Rector,

Dames en Heren toehoorders,

De beloning van wetenschap door de erkenning wan collega's is naar mijn mening, thet bereiken van het hoogste niveau in iemands professionele carrière. Dat zich binnen relatief korte tijd asn deze universiteit opnieuw een Hoogleraar in Verplegingswetenschap intreedt is verheugend en opmerkelijk. Het geeft de belangrijke plaats aan die de Vakgroep Verplegingswetenschap binnen deze universiteit en binnen de Faculteit Gezondheidswetenschappen inneemt. Hiermee wordt de bijdrage van de vakgroep zowel in het onderwijs alsook in het wetenschappelijk onderzoek erkend. In dit kader hecht ik zelf aan deze bijeenkomst een grote betekenis. Het moedigt mij aan een onderwerp te behandelen dat voor velen van u bekend is "Verplegingswetenschap en de verpleegkundige praktijk: Een onderlinge relatie".

In mijn betoog bespreek ik eerst de evolutie van verplegingswetenschap. Vervolgens zall ik nagaan wat het domein van verplegingswetenschap is en tenslotte tracht ik de samenhangen in kaart te brengen tussen de discipline, de wetenschap en de praktijk.

\section{De evolutie van Verplegingswetenschap.}

Mijn stelling wandaag luidt, dat verplegingswetenschap zich in een proces van "academische" evolutie bevindt. Deze evolutie heeft kenmerken die in het proces van ontwikkeling van het vak teruggevonden kunnen worden. Daarom kies ik als uitgangspunt, dat zelf-reflectie en zelf-analyse essentiële elementen zijn voor de verdere groei en ontwikkeling van het vakgebied.

Ik ben zelf geen historicus en ik stel er geen belang in orm de geschiedenis van de verpleging te beschrijven als een reeks historische evenementen. Mijn interesse ligt in de epistemologie: ik ben ervan overtuigd, dat bevordering van verpleegkundige kennis via het ontwikkelen en toetsen van verpleegkundige modellen en theorieèn, en voortschrijdende definiëring van het domein varn studie een significante bijdrage hebben geleverd aan de wetenschappelijke evolutie van onze discipline.

In het zoeken naar een professionele identiteit ging de werpleging door een aantal stadia in haar ontwikkeling tot een discipline en een wetenschap. In elk stadium werd een sandachtsgebied benadrukt, doelstellingen gekozen en kennis ontwikkeld. De verschillende stadia met hun karakteristieke diversiteit hebben hun bijdrage gelewerd aan de ontwikkeling van het vak tot een dicipline en een wetenschap.

Volgens Meleis (1985) bestaat er een chronologische ontwikkeling van verpleegkundige kennis (zie figuur 1). Het begon met de erkenning van verpleging als afzonderlijke beroepspraktijk en de betekenis daarbij van een voorloper als Florence Nightingale. De zorg voor zieken en invalliden in deze periode lag in handen van vrowwen. De periode van erkenning van het beroep geeft de verpleging de "Raison d"être" voor de ontwikkeling van verpleegkundige zorg. 


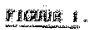

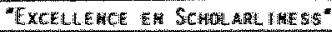

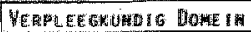

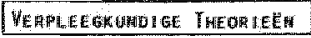

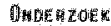

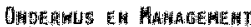

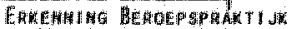

\begin{tabular}{rrrrrrrrrr}
50 & 55 & 60 & 65 & 70 & 75 & 80 & 85 & 90 & 95 \\
\hline
\end{tabular}

De ziekenwerpleging paste in deze periode in het oude patroon van caritas liefdadigheid. In die eerste jaren werd de werpleegster in een ziekenhuis opgeleid, meestal door medici. Vragen over het werk van de verpleegsters in de praktijk hebben geleid tot vragen over welke curricula of onderwijsprogramma"s ontwikkeld moesten gaan worden. Het experimenteren met curricula, methoden wan onderwijs en het opleiden van docenten hebben bijna drie decennia in beslag genomen. Dezelfide problematiek was cok evident in het management en de beleidssfeer. Deze periode werd gekarakteriseerd door het ontwikkelen wan expertise in de verpleging, het opleiden vart verpleegkundige docenten en verpleegkundige managers. Zodoende werd een andere dimensie an de vakkennis toegevoegd.

\section{Normen wan Wetenschap.}

Gelijkopgaande met de periode van onderwijs en management en zich baserend op gestelde vragen op beide gebieden ontstond de behoefte aan onderzoek. Hoe te leiden, hoe te onderwijzen, hoe te organiseren en welke strategieèn daarvoor te gebruiken waren volgens Gortner en Nahm (1977) de meeste onderzochte vragen van die tijd. In de jaren 1950 ontstond het eerste verplegingswetenschappelijke tijjschrift. Criteria voor het beoordelen van onderzoeksartikelen. werden dientengewolge ontwikkeld. Verpleegkundigen als onderzoekers begonnen de normen van Merton (1973) ower het universalisme wan wetenschappelijke kennis, ontwikkeld in een gemeenschap wan wetenschapsbeofenaren, te accepteren en te gebruiken. Universiteiten verwachtten ook van hun verplegingswetenschappelijke medewerkers dezelfde nomen als bij andere disciplines. Dat hield ook in, dat het motto in de wetenschap "Publish or Perish" norm werd.

Met die twee normen van wetenschap, universaliteit en communaliteit was de verplegingsdiscipline eenzelfde weg ingeslagen die vele wetenschappen eerder hadden afgelegd. Als gevolg van kritiek over iemands onderzoeksideeen en publicaties, ontwikkelde zich in die periode twee andere soorten nomen met namen "belangeloosheid" en scepticisme. De erste eist objectiwiteit en de tweede een kritische analyse van werk wolgens empirische criteria. De periode van onderzoek heeft een belangrijke bijdrage geleverd aan het ontwikkelen van curricula, aan het toepassen van organisatiemodellen binnen de verpleging, alsook het verspreiden wan wetenschappelijke publicaties in verschillende tijdschriften. 


\section{Theorievorming.}

De periode van het onderzoek werd ook gekenmerkt door "random fact gathering", volgens Kuhn (1970) slechts "the beginning of inquiry and the rudimentary beginning of science". Research in deze periode richtte zich veel meer op de methodologie en het proces van onderzoek doen, en in mindere mate op de inhoud. Op dat moment bestonden geen conceptuele modellen on de verkregen onderzoeksresultaten te verbinden.

Daarop volgde de periode wan theorievorming. Vragen naar de essertie, doelstellingen en de missie van de verpleging werden gesteld als ook naar de aard en het object van studie. Men ging filosoferen over de aard van verpleegkundige theorieên. Voor sommigen was het een onderdeel van geneeskundle, voor anderen een deel van biologische, natuur- en/of sociale wetenschappen. Verplegingswetenschap is niet te reduceren tot een van de bestaande wetenschappen meenden de yoomaamste leiders van de theorievorming in de verpleging, net zoals biologie niet te reduceren is tot natuurkunde. Er bestaat in de verpleging een intrinsieke autonomie, die in het begin nog met de ogen van andere wetenschappen naar het eigen object kijkt, maar daarma met een eigen gezichtspunt het object nader preciseert.

De theorieèn werden van fundamenteel belang voor het ontwikkelen van de discipline beschouwd. Ze gaven de discipline raamwerken om daarbinnen op eigen verschijnselen en problemen zich te kunnen concentreren. Vragen over fundamentele processen en analyse-eenheden hebben geleid tot het streven naar én universele theorie voor de verpleging. Pogingen tot het ontwikkelen van zulke theorieèn werden afgewezen gezien hun simplistische of reductionistische benadering. De voornaamste ontwikkelingen zijn thans:

1. - de vaststelling dat multiple paradigma's noodzakelijk zijn in verband met de complexiteit van het veld verpleging;

2. - het testen van bestaande theorieën en modellen; en

3. - de ontwikkeling van nieuwe theorieën gebaseerd op concepten uit het veld. Volgens Meleis (1985) wordt deze periode gekenmerkt door de normen van dualisme en pluralisme.

Het domein van de verpleging.

Verpleging als een professie heeft als doel het verlenem van zorg aan individuen, gezinnen en gemeenschappen. Om dit goed te kunnen doen is gefundeerde basiskennis over gezondheidszorg een eis. De inhoudelijke basiskennis is ontwikkeld door onderzoek dat zich richt op de respons van de mens bij feitelijke of potentiële gezondheidsproblemen, beinvloedende omgevingsfactoren en bijpassende interventies om problemen te behandelen of het gezondheidsstelsel te bevorderen.

Verpleging is zowel een professie als een discipline (zie figuur 2). De professie verpleging houdt zich bezig met de kwaliteit van zorg alsook de professionele activiteiten van haar hulpverleners. Een discipline is een uniek gemeenschappelijk domein van kennis, een eigen "body of knowledge". De discipline in de verpleging heeft twee delen; 1 . Verplegingswetenschap en 2. Professionele grondslagen. Daartoe behoren kennis over waarden van de professie, de aard van de klinische praktijk en de historische en filosofische basisbegrippen van de professie en de professionele praktijkuitoefening. 


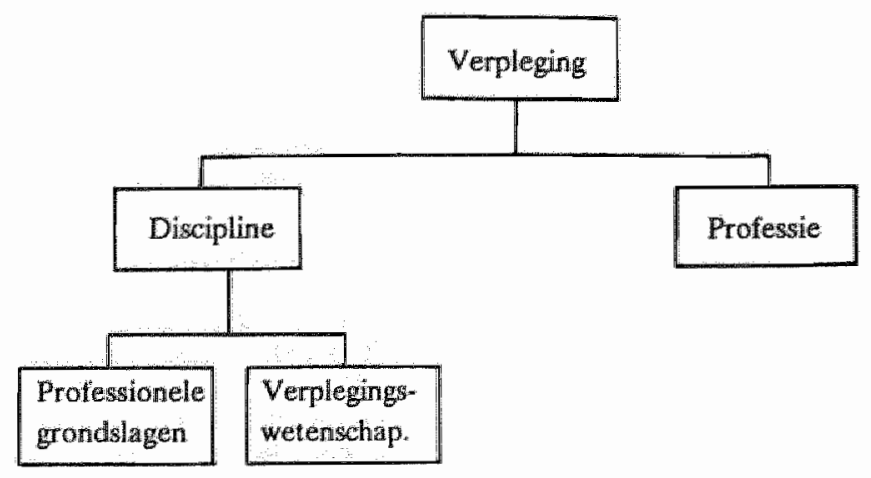

FGUUR 2

Verplegingswetenschap is het wetenschappelijk domein van kennis dat de verpleegkundige praktijk leidt. Het is kennis ontwikkeld door systematische studie. Zijn doelstellingen zijn gericht op het geven van vorm aan de verpleegkundige praktijk. Het domeir van de verpleging houdt zich bezig vooral met:

1. - het herkennen en analyseren van feitelijke of potentiële gezondheidsproblemen bij mensen;

2. - het definiëren van sommige gezondheidsproblemen als verpleegproblemen.

3. - het verrichten van therapeutische interventies om die problemen te verlichten of te voorkomen;

4. - het bestuderen en analyseren van beïnvloedende omgevingsfactoren op het bevorderen en tot stand houden van gezondheid.

\section{Kennisbronnen in de verpleging.}

Verplegingswetenschappelijke kennis vormt één deel van de discipline verpleging. Een breed gezichtsveld is nodig om de normen en waarden van de professie en filosofische grondbegrippen van de praktijk te kunnen hanteren. De professionele grondslagen in de verpleging zijn gebaseerd op verschillende methoden van studie, met name empirische observaties, ervaring, individuele kennis, en ethiek. Empirische kennis over het gedrag van mensen tijdens ziekte en gezondheid vormi de basis yoor de verpleegk undige praktijk. De aesthetische perceptie van significante ervaringen van mensen gepaard met een persoonlijk begrip voor de individualiteit van elke gewaarwording bevordert de aard van de verpleegkundige praktijk. De kennis dat elk individu thet vermogen heeft om morele beslissingen zelf te kunnen nemen beïnloedt ook het dagelijks routinegedrag van hulpverleners.

Het domein van de verpleging omwat kennis ower de werpleegkundige praktijk en evolueert uit de filosofie, geschiedenis, praktijkoefening, onderzoek en theorie. Gezien de genealogie in de verpleging en de grondbegrippen binnen de verplegingswetenschappelijke theorieên, is het begrijpelijk dat Verplegingswetenschap zich ontwikkelt in de richting van een wetenschap van 
de zorg. Zorg wordt hier als een kernbegrip beschouwd. De dimensies van dit begrip of wat wordt bestudeerd door Verplegingswetenschap worden als het object van wetenschap beschouwd. Hier wordt aandacht besteed aan een verheldering van wat betreft feitelijke of potentiële werpleegproblemen, hun processen en toestanden alsook de gerichte interventies die de problemen kunnen verlichten of voorkomen. De aard van de verplegingswetenschappelijke verschijnselen valt in vier hoofdcategorieën:

1. Verschijnselen die te maken hebben met de universele of fundamentele behoeften van mea sen.

2. Verschijnselen die te maken hebben met de bio-psychologische ontwikkelingen van mensen en hun relatie tot het bestaan van feitelijke of potentiele problemen met name:

a. - de overgangsperiode van kinderen tot adolescenten en wat dat op zich in beweging brengt in de vorm van 0.a. drugsgebruik en tienerzwangerschap;

b. - de overgang van vollwassenheid naar ouderdom brengt ook problemen in de sfeer van identiteitscrisis, zelfzorgvermogen en chronische ziekten.

3. Verschijnselen die te maken hebben met situationele transities zoals de geboorte wan een kind of een verlies van cen familielid. Verpleegkundigen hebben ook veel te malken met overdracht wan zorg van intra- naar extramurale instellingen.

4. Verschijnselen die te maken hebben met het gezondheid / ziekte continuüm met narne de overgang van gezondheid naar een acute ziektesituatie of van acute ziektetoestand naar een chronische toestand.

Het domein wordt beschreven niet alleen door het object van de studie maar ook door de aard van de gestelde vragen over het object van de studie. Flke discipline beziet dezelfde verschijnselen vanuit de eigen invalshoek, stelt eigen vragen. Verplegingswetenschap is geïnteres seerd in hoe de mens als een bio-psychosociaal en cultureel systeem functioneert en hoe veranderingsprocessen in verband met gezondheid en ziekte het gedrag van de mens beimvloeden. $\mathrm{De}$ verpleging is verantwoordelijk voor de toepassing van deze kennis in de praktijk. Het bovenstaande impliceert een zelfstandige ontwikkeling van de Verplegingswetenschap, die richting geeft aan de dlaadwerkelijke verpleging en verzorging.

Indien de verplegingswetenschap zich niet bezighoudt met de studie van deze verschijnselen, wie doet het dan wel? De kern van de studie in Verplegingswetenschap blijft het stellen van eigen vragen aan het object: de praktijk van het verplegen en werzorgen. Andere soorten studies op meso- en macroniveau naar de beroepsuitoefening blijven van groot belang voor de professionalisering van de verpleegkunde maar ze leveren relatief weinig op woor de ontwikkeling van het domein Verplegingswetenschap.

\section{"Excellence" in Wetenschap.}

De "commitment to excellence" in het ontwikkelen van wakinhoudelijke kennis of de wetenschap is naar mijn mening van belang voor het ontwikkelen van de professie verpleging. "Excellence" in wetenschap wordt gekemmerkt door:

1. - de diepgang van de gefundeerde kennis;

2. - de mate waarin onderzoek grensverleggend is (Hinshaw, Heinrich \& Block, 1989).

Diepgang in kennis houdt in dat men talrijke studies doet die dezelfde onderwerpen behandelen en resulteren in overeenkomstige resultaten. Het is alleen wia de replicaties wan studies bij 
verschillende $k$ linische populaties, dat verpleegkundigen overtuigd kunen worden van de geloofwardigheid en effectiviteit van de beoogde onderzoeksresultaten. In het verleden hebben verplegingswetenschappers "shotgun" studies verricht, dat wil zeggen een studie binnen een bepaald gebied vervolgd door een andere in een totaal ander gebied. Dit gebeurde omdat;

1. - onderzoekers in verschillende gebieden en voor verschillende rollen nodig waren, bijvoorbeeld als managers, onderwijzers en clinicit;

2. - onderzoekers én of twee studies hebben kunnen uitvoeren en daarna betrokken worden bij andere professionele rollen;

3. - de verpleging toen geen onderzoekstraditie had of carrièreperspectief in de wetenschap om onderzoeksprogramma's te ontwikkelen. Dit werd met name veroorzaakt door te weinig middelen op dit gebied.

Met de continue groei van de middelen en van het kader van verplegingswetenschappers zijn er tegenwoordig meer onderzoekprogramma's te vinden. Hier wordt met onderzoekprogramma's bedoeld, een serie wan studies op hetzelfde gebied, elk voortbouwend op de resultaten wan de andere en elk bijdragend aan de verdere ontwikkeling van kennis op dat gebied. Met de groei wan het kader van wefenschappers met carrièreperspectieven binnen de verpleging en door het gebruik maken van replicatiestudies en elkaars resultaten, groeit ook de noodzaak voor meer diepgang in de werplegingswetenschap. Hoewel diepgang van belang is blijft het brede gezichtsveld van de verpleegkundige zorg een probleem in het ontwikkelen van kennis. Dit vereist een systematische benadering van de problematiek door het specificeren van prioriteiten voor onderzoeksgebieden voor de verpleegkundige praktijk. Wanneer men prioriteiten stelt in de beofening van de Verplegingswetenschap zal naar mijn mening, een sneller resultaat bereikt worden, dat meer diepgang en relewantie heeft.

Diepgang in Verplegingswetenschap kan ook vergemakkelijkt worden door nauwe samenwerking met andere basis- en velddisciplines in de gezondheidszorg. De complexiteit en de aard van de vraagstukken in de verpleging eisen een multidisciplinaire benadering die van fundamenteel belang is voor ontwikkeling van verpleegkundige kennis.

De tweede uitdaging voor Verplegingswetenschap is grensverleggend te zijn en te blijven en daarmee bij te dragen tot maatschappelijk relevante onderzoeksprogramma's in de gezondheidszorg. Verplegingswetenschappelijk onderzoek kan niet en mag zich niet in een vacuum blijwen ontwikkelen. Het moet tegemoet komen aan de behoeften en de eisen van de maatschappij. Er is niets gewonnen met het ontdekken van al bekende informatie bij andere disciplines. Het voegt weinig toe aun de discipline en de universele kennis. Het samenwerken met andere disciplines en het uitwisselen wan kennis en deskundigheid binnen bepaalde gebieden met wetenschappers van andere disciplines, kunnen, in tegenstelling, de ontwikkeling van kennis versterken en bevorderen.

\section{Relatie tussen de Discipline, de Wetenschap en de Praktijk.}

Verpleging als een discipline is voornamelijk bezig, meer dan in andere disciplines, met het bestuderen valm de basisbegrippen van haar praktijkuitoefening. Geneeskundig onderzoek is vooral gericht op de basisdisciplines en de resultaten ervan hebben niet noodzakelijk directe relevantie voor de problemen uit de praktijk. Er is behoefte volgens veel medici voor een wetenschap wan "doctoring" of de wetenschap van de geneeskundige praktijk. In de verpleging bestaat 
tot heden geen traditie of een systeem van waarden die de aard van de wetenschappelijke vratigstukken beoordeelt. Hier hoeft de verpleging de stappen van andere disciplines niet te volgen in haar ontwikkeling tot een professie.

Het analytisch bestuderen van het werk in de praktijk is een uitdagende, vaak weerbarstige en soms pijnlijke ervaring die veel openheid, flexibiliteit en vooral veranderingsvermogen vraagt. Verpleegkundigen zijn constant bezig geweest met verandering en verbetering van hun werk in relatie tot de behoeften van de maatschappij. Nieuwe ontwikkelingen in de gezondheidszorg hebben verder een vergroting van de kennis, deskundigheid en bekwaamheid van de verpleegkundige gevraagd. Onderzoek helpt deze veranderingsprocessen, wanneer zorgwuldig opgezet, naar een relevante en effectieve manier van zorgverlening in de verpleegkundige praktijk. Hoe hechter de relatie is tussen het verplegingswetenschappelijk onderzoek en de verpleegkundige praktijk, hoe beter het onderzoek is en hoe beter de praktijk wordt.

Op weg naar een belangrijke plaats in de gezondheidszorg heeft de verpleging als een professie het gereedschap van de wetenschap nodig. Het valt moeilijk te argumenterea, dat verpleegkundige zorg de kwaliteit van zorg kan beïnvloeden zonder de aanwezigheid van voldoende kennis. Verpleegkundigen nemen tegenwoordig veel meer verantwoordelijkheid in de intra- en extramurale zorgsector, en hun functies en taken worden regelmatig uitgebreid met taken die tratditioneel bij artsen horen. Daarom is het bewijs van de eigen bijdrage van groot belang.

Deze introductie brengt mij tot mijn derde punt in dit betoog, welk gaat over de relatie tussen de discipline, de wetenschap en de praktijk en in het bijzonder wat de discipline en de wetenschap aan de praktijk bijgedragen hebben. Als eerste wil ik benadrukken, dat Verplegingswetenschap zijn bijdrage heeft geleverd aan het tot stand komen van de professie "verpleging". Verplegingswetenschap neemt volgens Jennings (1986) de verantwoordelijkheid voor het ontwikkelen van de "body of knowledge" welke inherent aan de statuten van een professie is. Deze unieke "body of knowledge" geeft autonomie en rationaliteit voor de zelfstandige verrichtingen en acties van verpleegkundigen in de praktijk.

De relatie tussen de discipline en de wetenschap wil ik toelichten met de relatie Verplegingswetenschap en onderzoek. Onderzoek is volgens Hinshaw (1989) geen wetenschap maar het gereedschap of de tool van de wetenschap. Het ontwikkelen van kennis is echter een interactie tussen wetenschap en onderzoek. Verplegingswetenschappelijke kennis is enerzijds gefundeerd in onderzoek; verplegingswetenschappelijke kennis geeft anderzijds het raamwerk waarbinnen verpleegkundig onderzoek verricht kan worden. De wetenschap stelt in andere woorden het domein vast en geeft richting aan het onderzoek. Verpleegkundige verschijnselen, waaruit het domein bestaat, zijn dientengevolge aan het evolueren en hebben geleid tot het ontwikkelen van conceptuele ramwerken op verschillende gebieden. Hier will ik een tantal noemen:

1. Het werk van Mercer (1981) richtte zich op factoren die de moederrol beïnvloeden.

2. Norbeck's (1981) werk op het gebied van "social support" heeft gelleid tot een verheldering van het verschijinsel en haar mogelijke toepassing in de praktijk.

3. Het werk van Johnson et al. (1974) over het voorbereiden van patiënten door specifieke voorlichting is wan groot belang woor de verpleegkundige praktijk.

Zelf ben ik de laatste tien jaar bezig geweest met het bestuderen van pijn bij kinderen. Mijn onderzoek begon met een praktijkverkenning dat veel kinderen onnodig pijn lijden en dat in de 
praktijk weinig gedaan werd ter bestrijding en voorkoming van pijn. Ik begon met empirische obserwaties uit de praktijk. Deze werden gevolgd door een empirisch onderzoek met als doel de aard van pijn bij kinderen te beschrijven alsook de incidentie, prevalentie wan die pijn bij verschillende klinische populaties te inwentariseren. Tegelijkertijd rakte ik geinteresseerd in de factoren die de pijn bij kinderen kunnen beinvloeden met name de ontwikkelingsstadia van kinderen, de psychologische toestand wat bijwoorbeeld angst en vrees betreft, de invloed van de ouders alsook de maatschappelijke en culturele verwachtingen ten aanzien van pijn, pijnperceptie en pijnrespons. Onderzoeksstudies over dit onderwerp waren er toen heel weinig of bestonden helemaal niet. Resultaten van door mij verrichtte studies in Amerika bevestigde de ainwezigheid en hoeveelheid van de ervaren pijn bij kinderen, stelde de kenmerken van de pijn bij verschillende klinische populaties vast, en werklaarde de rol die de cultuur speelt in de pijnbeleving.

Als gevollg en gebaseerd op de eerste resultaten richtte mijin aandacht zich op de manieren waarop pijn bij kinderen vastgesteld werd. Met andere woorden welke methoden worden in de praktijk gebruikt om pijn te beoordelen en vast te stellen. Dit heeft geleid tot een validering van een meetinstrument bij kinderen in de leeftijd van zeven tot vijftien jaar. Dankzij een sabbatsverlof in Parijs en mijn cross-cultureel pijnonderzoek in Amerika is het mij mogelijk geweest de culturele dimensie van pijn in mijn onderzoek verder te verklaren en te versterken. De laatste vier jaren in Nederland hebben mij ook veel geleerd, niet alleen over pijnperceptie en pijnrespons bij Nederlandse kinderen, maar tok over de factoren die de verpleegkundigen beïnwloeden in hun pijnbeoordeling en pijnverlichting. Een aantal onderzoeksstudies werden in die periode verricht. Als eerste het vaststellen van pijn bij 50 gehospitaliseerde Nederlandse kinderen aan de hand van een vragenlijst. De resultaten van het eerste onderzoek werden vervolgens bij 355 gezonde kinderen getoetst. Dit heeft geleid tot het ontwikkelen van een vragenligst die de intensiteit alsook de kwaliteit van pijn bij kinderen meet. Deze vragenlijst werd daarna getoetst bij postoperatieve pijn woor en na het toedienen van pijnstillende middelen. De construct alsook de discriminante validiteit werden zodoende als gevolg bevestigd. Het vaststellen van pijn aan de hand van de vragenlijst bij kinderen met kanker, reuma en postoperatieve pijn leverde informatie op wat betreft het pijnprofiel bij de verschillende klinische populaties.

Ik ben op dit moment mijn studenten dankbaar voor hun interesse in het verrichten van onderzoek over pijn bij kinderen en voor hun bijdrage aan het verder ontwikkelen van kennis op het gebied. Onze samenwerking heeft geleid tot het ontwikkelen van een valide en betrouwbaar meetinstrument om pijn bij kinderen in de eerste instantie vast te kunnen stellen en om de effectiviteit van de beoogde interventie goed te kunnen toetsen.

De resultaten van onderzoek over de laatste 10 jaar zijn in het volgende model (zie figuur 3) of ramwerk samengevat: Beinvloedende factoren zoals de leeftijd de cognitie, het gezin en de cultuur de pijnperceptie, pijnervaring en pijnrespons beinvloeden. Situatiespecifieke factoren zoals de klinische toestand, de mening over en aard van pijn alsook de verwachtingen over de intensiteit en duur van pijn kunnen de pijnervaring ook beinvloeden. Psychologische factoren tenslotte zoals de aanwezigheid van angst en vrees alsook de te gebruiken coping mechanismen kunnen een invloed uitoefenen op de pijnrespons van kinderen. 
CONCEPTUEE RAAMERK OVER PUN BUI KURDERE.

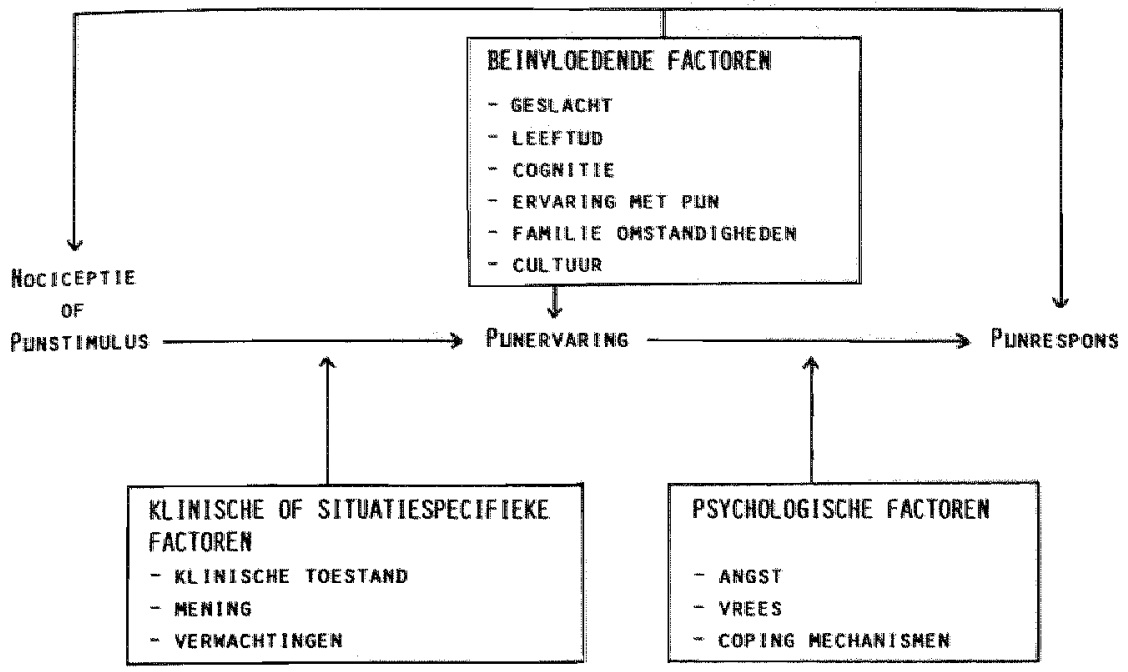

FICtur 3.

Voor de verplegingswetenschapper en de werpleegkunde is pijn een subjectieve multidimensionele gewaarwording die niet alleen door het gedrag of de fysiologische veranderingen vastgesteld kan worden maar cok door de uitingen van de perscon zelf die aan pijn lijdt. Zodra dat de zorgvraag vastgesteld wordt, moet de verpleegkundige aan die vraag tegemoet komen door het verrichten van effectieve behandelingen om die pijn te verlichten. De effectiviteit van de verrichte interventies worden in mijn tegenwoordig onderzoek getoetst.

Dames en heren, ik wil aan dit onderwerp niet langer tijd besteden, hoewel ik er natuurlijk persoonlijk zeer bij betrokken ben. Het is in dit kader als voorbeeld gebruikt om de relatie onderzoek / praktijk te bevestigen. Onderzoeksprojecten van deze aard zijn er tegenwoordig in overvloedige mate: slaap-, mobiliteits-, voedings- en defecatieproblemen, om maar een aantal te noemen. Patiëntenvoorlichting in de vorm van voorbereiding op operatie of onderzoek, instructie van patiënten over mogelijke consequenties en gevolgen van bepaalde behandelingen, zoals het informeren van diabetici en CARA-patiënten over het gebruik van geneesmiddlelen, over voedingspatronen en het verspreiden wan informatie en toelichtingen alan de bevolking in thet voorkomen van hart en vaatziekres, AIDS en besmettelijke aandoeningen. Het yoorkomen van decubitus door het gebruikmaken van wisselligging, speciale matrassen of andere hulpmiddelen wordt in de praktijk toegepast als gevolg van onderzoek. Het werk in de psychiatrie en de oncologie en met bejaarden is ook recent door onderzoek beïnvloed.

Ondanks alle ontwikkelingen in de theorie en de wetenschap blijft de kloof met de praktijk nog, groot. Wat men in de wetenschap bestudeerd heeft, moet volgens velen direct de praktijk kunnen beïnvloeden. Meestal is er een owerdreven optimisme, dat wil zeggen dat zodra onderzoeksresultaten bekend worden, snel zal moeten worden bewezen dat alles beter en efficiènter in de verpleging kan gebeuren. Dat is gelukkig niet altijd waar en zeker niet op korte termijn. 
Toepassingen in de praktijk kunnen pas plaatsvinden in de aanwezigheid van replicaties van onderzoeksresultaten bij verschillende klinische populaties en instellingen. Dit vraagi dus niet alleen breedte in onderzoek maar ook diepte. Zodra die informatie door de wetenschap vastgesteld wordt, wordt wan de verpleegkundige manager verwacht de nieuwe ontwikkelingen in de kennis in de praktijk toe te passen. In dit opzicht is de taak van de leidinggevende verpleegkundige alsook de verpleegkundige beroepsbeofenalar in het vertalen en toepassen van onderzoeksresultaten in de praktijk van groot belang. Samenvattend zijn theorie en onderzoek de processen waarbij de domein concepten ontwikkeld, gevalideerd en gecommuniceerd worden. De praktijk, bet onderwijs en het management zijn werantwoordelijk voor het gebruikmaken van de ontwikkelde kenris.

\section{Dames en Heren,}

Tot nu toe heb ik in het algemene gesproken over het domein van de verpleging en de plaats van de Verplegingswetenschap daarin. Nu wil ik mijn gedachte richten op de beofening van de Verplegingswetenschap in Maastricht en de ontwikkelingen daarin voor de toekomst.

De Faculteit der Gezondheidswetenschappen viert dit jaar zijn 10-jarig bestaan en de Vakgroep Verplegingswetenschap heeft ook zijn 10 -jarig bestaan gevierd. Beide zijn in het laatste decennium heel veel gegroeid. De afstudeerrichting Verplegingswetenschap is gegroeid van een gemiddelde van 20-30 studenten per jaar tot 200 studenten per jaar. Dat is zeker opmerkelijk! De belangstelling voor een academische opleiding van verpleegkundigen neemt zeker toe. Het ontwikkelen van part-time en full-time doorstroomprogramma's binnen de afstudeerrichting Verplegingswetenschap heeft deze situatie gemakkelijker gemaakt. Het curriculum ontwikkelt zich voortdurend en is veel evenwichtiger geworden. De studie wordt door studenten positiever geèvalueerd wat betreft inhoud en relevantie. Dit zijn belangrijke bereikte resultaten voor de vakgroep op het lokale niveau. Op landelijk niweau geeft de samenwerking met Utrecht en Groningen en sterke impuls aan het verder ontwikkelen en uitbreiden van Verplegingswetenschap in Nederland. Op Europees niveau zijn er verschillende contacten gelegd met Franse, Engelse en duitstalige universiteiten voor mogelijke uitwisselingsprogramma's voor docenten en studenten. En op internationaal niveau is de samenwerking met Wayne State University in Detroit van start gegaan en zal in de toekomst sterker worden.

Op het onderzoeksgebied heeft ook de vakgroep zich ontwikkeld. Eien aantal ledlen zijn al gepromoveerd of zijn bezig. Omdat de onderzoeksprioriteiten bij de vakgroep van klinische aard zijn, is werdere uitbouw van de samenwerking met de praktijk in de regio en landelijk van groot belang. De relevantie en uitvoerbaarheid van het onderzoek worden dus kritischer bekeken. Het creèren van een verplegingswetenschappelijk onderzoeksproject binnen de universiteit is dus van belang om de krachten van de onderzoekers op dit terrein te bundelen. Dit kan gebeuren in sameriwerking met andere basis- en velddisciplines.

Samenwerking met wetenschappers in andere disciplines kan naar mijn mening, de waardering en bekendheid van het vakgebied alleen maar vergroten. Op landelijk en internationaal niveau windt momenteel dergelijke samenwerking plaats binnen een aantal projecten van de vakgroep. 
Het verspreiden van onderzoeksresultaten door het presenteren op nationale en internitionale conferenties alsook het publiceren in internationale tijdschriften zijn onmisbare kenmerken van een wetenschappelijke staf. Onze bijdrage als vakgroep op dit gebied zal in de toekonst groter moeten gaan worden.

De professionalisering van de verpleging als een beroep is afhankelijk van de ontwikkelde wetenschappelijke vakkennis. De verpleegkundige zal op basis van wetenschappelijke argunnenten in toenemende mate de inhoud en de vorm gaan bepalen voor de eigen plaats en functie in de gezondheidszorg. De samenwerking van deze vakgroep met het academisch ziekenhuis te Maastricht en met het veld zal meer gestalte gaan krijgen in de toekomst. Hiermee bevestig ik ook de verantwoordelijkheid die het veld heeft genomen voor de toekomstige ontwikkelingen van het vak. Het is mij een bijzondere eer de gelegenheid te krijgen om aan dit stadium van ontwikkeling van de verpleging in Nederland een bijdrage te kunnen leveren.

Collega Philipsen, beste Hans,

Jouw steun, inzet en vooral je bellangstelling in verplegingswetenschap zijn opmerkelijk. Je hebt wat mij betreft een stempel gedrukt op deze historische ontwikkeling van verplegingswetenschap in Nederland. Bij deze mijin dank.

Collega wan den Bergh-Braam, beste Anneke,

Alls eerste buitengewoon hoogleraar in de verplegingswetenschap heb jij een significante bijdrage geleverd aan deze landelijke ontwikkeling. Ik dank je voor jouw steun.

Beste leden van de vakgroep,

Ik ben ervan overtuigd, dat wij samen aan de toekomstige uitdagingen op het terrein van onderwijs en onderzoek van Verplegingswetenschap een belangrijke bijdrage kunnen gaan leveren. Hierbij zijn mijn overtuiging en optimisme groot. Ik wil niet nalaten mijn waardering uit te spreken voor het waarnemen van het voorzitterschap door Harrie Smeets.

Beste Ernst, Michael en Carla,

Het is door jullie steun, aanmoediging en liefde, dat ik deze stap heb kunnen nemen. Enst, mijn carrière heb je altijd gesteund en gerespecteerd. De uitdagingen in ons leven hebben ons dichter bij elkaar gebracht. Voor dit ben ik dankbaar.

Dear mother,

You have been all allong an inspiration to me personally and professionally. Your caring and loving nature has influenced and will continue to influence our lives. I am thankful to God for making your presence at this special occasion possible.

Tenslotte dank ik allen die een rol hebben gespeeld en mijn benoeming mogelijk makakten.

Beste aanwezigen,

Ik dank u vooral voor uw aandacht en aanwezigheid. 


\section{Literaturur.}

* Abu-Saad, H. (1984). Cultural Group Indicators of Pain in Children Maternal Child Nursing Iournal. 13, 187-196.

* Abu-Saad, H. (1984). Assessing Children"s Responses to pain. Pain; 19, 162-171.

* Abu-Sad, H. (1990). Towards the Development of an Instrument to assess Pain in Chidren: Dutch shdy In: Tyler, D.C. Krane, J.E. (Red). Advances in Pediatric Pain Research and Therapy. Pediatric Pain. New York, Raven Press.

* Abu-Siad, H., Kroonen, E. Halfers, R. (1990). On the Development of a Multidimensional Dutch Pain Assessment Tool for Children. Pain, 43, 249-256.

* Gortner, S. (1980). Nursing Science in Transition, Nursing Research, 29, 180-183.

* Gortner, S.R. and Nahm, H. (1977). An overview of Nursing Research in the United States. Wursing Research, 26, 10-12,

* Hinshaw, A.5., Heinrich, J. and Block, D. (1989). Evolving Clinical Research Priorities, Journal of Professional Nursing, 4(6), 398, 458-459.

* Jennings, B.M. (1986). Nursing Science: more promise than threat. Journal of Advanced Nursing, $11(5), 505-511$.

* Johnson, J.E. and Rice, V.H. (1974). Sensory and Distress Components of Pain: Implications for the Study of Clinical Pain. Nursing Research, 23, 203-209.

* Kuhn, T.S. (1970). The Structure of Scientific Revolutions 2nd Edition. The Univer sity of Chicago Press, Chicago.

* Meleis, A.I. (1985). Theoretical Nursing: Development and Progress. Lippincott, Philadelphia.

* Mercer, R. (1981). A Theoretical Framework for Studying Factors that Impact on the Maternal Role. Nursing Research, 30, 73-77.

* Merton, R.K. (1973). The Sociology of Science: theoretical and Empirical Implications. The University of Chicago Press, Chicago.

* Norbeck, J. (1981). Social Support: A Model for Clinical Nursing Research and Application. Advances in Nursing Science, 3, 43-59. 